\title{
Community Awareness and Evaluation of Surface Water Bodies in Osogbo, Osun State, Nigeria
}

\author{
*ADEJUWON, JO; ADEKITAN, AA; OLADUNMOYE, SL \\ Department of Water Resources Management and Agrometeorology, Federal University of Agriculture, Abeokuta \\ *Corresponding Author Email: adejoseph2003@yahoo.com
}

\begin{abstract}
This study covers the examination of socio-economic characteristics of residents, identification of different types of surface water bodies, determination of level of accessibility of those water bodies, the evaluation of the water bodies and the identification of the challenges being faced by communities in Osogbo, Osun State, Nigeria using four hundred (400) well-structured questionnaires. Data obtained were analyzed using frequency counts and percentages with Statistical Package for Social Sciences (SPSS) version 15. Result showed that, 58.3\% were married, the male $(54.2 \%)$ respondents were higher than the females, and the occupation of the majority were informal sector $(37.1 \%)$. Also, the highest age group was $15-25$ years (34.3\%) while family size of 2-3 members $(61.1 \%)$ were higher than the other categories. Educational qualifications ranged from 2.2\% - Primary School Certificate holders to 30.5\% - NCE/OND/HND (30.5\%) graduates. Eighty-one percent of the respondents were aware of the water bodies. River $(37.7 \%)$ and stream $(38.1 \%)$ were the major water sources in the study area, and one of the rivers was dammed and used for religious and traditional purposes. The Rate of obtaining the water varied from regularly (19.6\%) to rarely (28\%) while the Reasons for obtaining water ranged from its natural state $(5.9 \%)$ to lack of portable water source (27.4\%). Approximately fifty-three percent $(52.7 \%)$ respondents had contacted one disease or the other ranging from bilharzias $(6.2 \%)$ to malaria $(18.1 \%)$ due to the use of the water while scarcity during the dry season has often resulted in frequent clashes among most users. Therefore, this study suggests that government and its agencies should provide portable water, care and maintenance of surface water bodies.
\end{abstract}

\section{DOI: https://dx.doi.org/10.4314/jasem.v22i10.06}

Copyright: Copyright $\left({ }_{0} 2018\right.$ Adejuwon et al. This is an open access article distributed under the Creative Commons Attribution License (CCL), which permits unrestricted use, distribution, and reproduction in any medium, provided the original work is properly cited.

Dates: Received: 20 September 2018; Revised: 20 October: 2018; Accepted: 29 October 2018

Keywords: public perception; surface water; disease; Nigeria

Water is the most popular and important liquid for all living things but considered as being polluted when it is detrimental for its planned utilization. Davis et al. (2003) reported that the growing demands for water and increased pollution loads threaten the quality of many lakes, rivers, estuaries and groundwater bodies and pose serious threats to public health, agricultural and industrial production, ecological functions, and biodiversity. Urbanization especially in the developing countries makes urban environmental sustainability critical and environmental impacts occurring at an unprecedented rate (Marsalek et al., 2006). With the advent of increasing population and industrialization, the range of requirements for water has increased, together with greater demand for higher water quality (Turdukulov, 2003). The use of water for a variety of human activities include drinking, personal hygiene, fishing, agriculture, industries, transport, recreation and suitable medium to clean, disperse, transport and dispose wastes since the ancient times. The human right to water entitles everyone to sufficient safe, acceptable, physically accessible water environment (Ki-moon, 2010). On 28
July 2010, the United Nations General Assembly Resolution A/RES/64/292 clearly recognized the human right to water and sanitation and accepted that clean drinking water and sanitation are crucial to the realization of all human rights. Therefore, enhancing surface water bodies in provision of viable, reliable water of acceptable quantity and quality for domestic and industrial uses is essential to healthy living, poverty alleviation and sustainable socio-economic development. However, in many rural communities, the lack of access to water (or inadequate control) contributes to the difficulty of generating acceptable yields. To minimize future human water shortages and undesirable environmental impacts, more equitable sharing of water resources between society and nature is required. This will require physical quantities and social values to be placed on both human and aquatic ecosystem requirements. Current water valuation systems are dominated by economic values and there is need for new quantification and valuation methods that take more account of human well-being and environmental impacts in rural communities of Osogbo. In the light of this experience, it become 
compelling and necessary to initiate a study aimed at the public perception and evaluation of surface water bodies in Osun State, Nigeria. Hence, the objective of this study is to investigate community awareness of various surface water body related issues in Osogbo, Osun State.

\section{MATERIALS AND METHODS}

The Study Area: Osogbo is the capital city of Osun State. The city seats the headquarters of both Osogbo
Local Government (situated at Oke Baale area of the city) and Olorunda Local Government Area (situated at Igbonna area of the city). Osogbo is situated between latitude $7^{\circ} 44^{\prime}$ and $7^{\circ} 49^{\prime}$ North and longitude $4^{\circ} 30^{\prime}$ and $4^{\circ} 35^{\prime}$ East, with an area of $47 \mathrm{~km}^{2}$ (Figure 1) Osogbo shares boundary with Ikirun, Ilesa, Ede, Egbedore and Iragbiji and it is easily accessible from any part of the State, because of its central nature. The major rivers in the area are: Osun River, Erinle River, and Otin River.

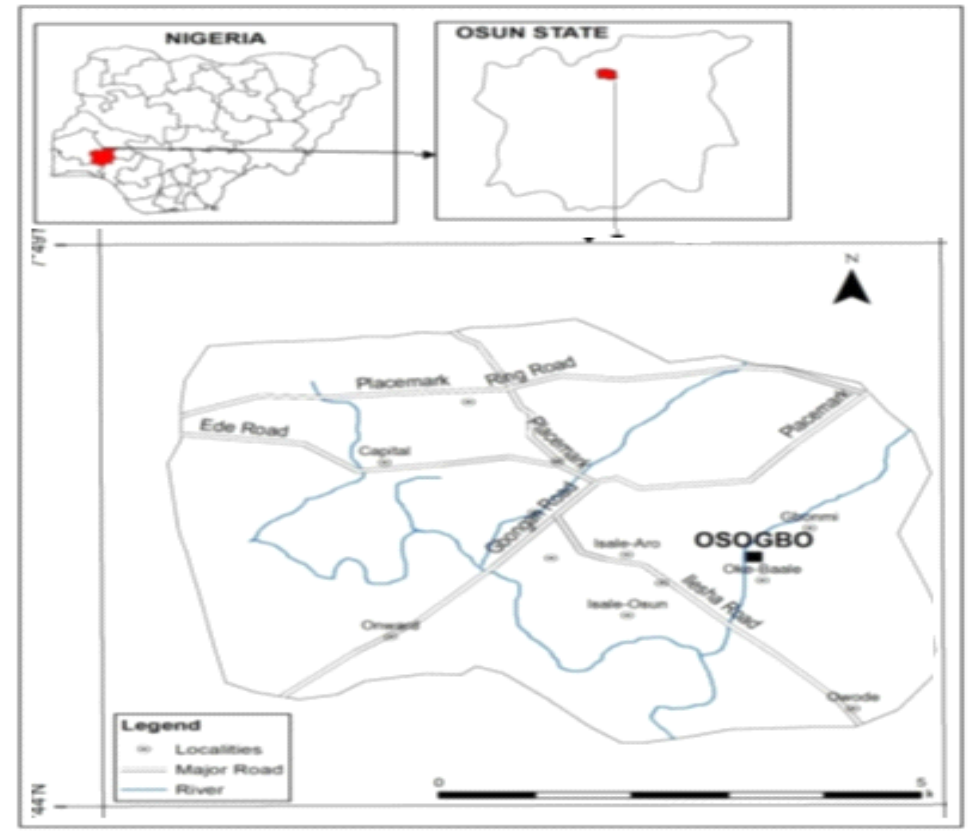

Fig 1: Map of Osogbo showing the study locations.

Data Collection: Primary data were generated from the residents of Olorunda and Osogbo Local Government Area. Four Hundred (400) wellstructured questionnaires were administered to the respondents of Osogbo in 2016.

Sampling: The stratified sampling technique was employed for the data collection. The samples were chosen based on the Local Government Areas, Wards, and Residential Location. 200 questionnaires were administered to Olorunda and Osogbo Local Government Area respectively.

Data Analysis: The data collected were analyzed using frequency counts, percentages and cumulative frequency. The data collected was analyzed using Statistical Package for Social Sciences [SPSS] (version 15).

\section{RESULTS AND DISCUSSIONS}

Table 1 shows the demographic characteristics of the respondents in Osogbo, in terms of their sex, age, occupation, marital status, family size and educational background. The male $(54.2 \%)$ were more than the female $(45.8 \%)$ respondents while the ages of the respondents ranged from $15-25$ years $(34.3 \%)$ to 56 years and above $(6.2 \%)$. About sixty percent $(58.3 \%)$ were married while $41.7 \%$ were singles. The occupational background varied from unemployed $(3.7 \%)$ to informal sector $(37.1 \%)$. The family size of the respondents ranged from 2 to above 10 members but those with 2-3 members were the highest (61.1\%). Educational qualifications of the respondents varied from Primary School Leaving Certificate to $\mathrm{PhD}$. Respondents with Primary School Certificate (2.2\%) were the lowest while those with NCE/OND/HND $(30.5 \%)$ were the highest. Table 2 shows the respondents perception of surface water in the study area. About $81.0 \%$ were aware of the surface water within their locality while $19.0 \%$ claimed they were not. The types of surface water bodies identified by the respondent include river $(37.7 \%)$, stream $(31.8 \%)$, rivulets $(4.0 \%)$, ponds $(5.3 \%)$ and lakes $(2.2 \%)$. 
Table 1: The demographic characteristics of the respondents in

\begin{tabular}{|c|c|c|c|}
\hline \multirow{2}{*}{\multicolumn{2}{|c|}{$\begin{array}{ll} & \text { Osogbo } \\
\text { Variables } & \end{array}$}} & \multirow{3}{*}{$\begin{array}{c}\text { Frequency } \\
174\end{array}$} & \multirow{3}{*}{$\begin{array}{c}\% \\
54.2\end{array}$} \\
\hline & & & \\
\hline \multirow[t]{3}{*}{ Sex } & Male & & \\
\hline & Female & 147 & 45.8 \\
\hline & Total & 321 & 100 \\
\hline \multirow[t]{6}{*}{ Age } & $15-25$ years & 110 & 34.3 \\
\hline & $26-35$ years & 97 & 30.2 \\
\hline & 36- 45 years & 31 & 9.7 \\
\hline & $46-55$ years & 63 & 19.6 \\
\hline & Above 56 years & 20 & 6.2 \\
\hline & Total & 321 & 100 \\
\hline \multirow{3}{*}{$\begin{array}{l}\text { Marital } \\
\text { Status }\end{array}$} & Single & 134 & 41.7 \\
\hline & Married & 187 & 58.3 \\
\hline & Total & 321 & 100 \\
\hline \multirow[t]{6}{*}{ Occupation } & $\begin{array}{l}\text { Farmer } \\
\text { Informal sector }\end{array}$ & $\begin{array}{c}76 \\
119\end{array}$ & $\begin{array}{l}23.7 \\
37.1\end{array}$ \\
\hline & Self employed & 31 & 9.7 \\
\hline & Civil servant & 79 & 24.6 \\
\hline & Unemployed & 12 & 3.7 \\
\hline & No response & 4 & 1.2 \\
\hline & Total & 321 & 100 \\
\hline \multirow[t]{5}{*}{ Family Size } & $\begin{array}{l}2 \text { members } \\
\text { 3-5 Members }\end{array}$ & $\begin{array}{c}29 \\
196\end{array}$ & $\begin{array}{c}9 \\
61.1\end{array}$ \\
\hline & 6-10 Members & 58 & 18.1 \\
\hline & Above 10 members & 13 & 4 \\
\hline & No response & 25 & 7.8 \\
\hline & Total & 321 & 100 \\
\hline \multirow{8}{*}{$\begin{array}{l}\text { Educational } \\
\text { Qualification }\end{array}$} & Primary school & 7 & 2.2 \\
\hline & Senior Sec School & 67 & 20.9 \\
\hline & NCE/OND/HND & 98 & 30.5 \\
\hline & B.A/B.Sc./B.Ed. & 89 & 27.7 \\
\hline & M.A/M.Sc./M.Ed. & 23 & 7.2 \\
\hline & Ph.D. & 23 & 7.2 \\
\hline & $\begin{array}{l}\text { Professional } \\
\text { qualification }\end{array}$ & 14 & 4.4 \\
\hline & Total & 321 & 100 \\
\hline
\end{tabular}

The use of surface water in the study area is shown in table 3. The reasons given by the respondents for obtaining surface water ranged from preference for the natural state of the water (5.9\%) to inability to obtain water from public sources $(27.4 \%)$ while the rate of obtaining the water varied from regularly $(19.6 \%)$ to rarely $(28.0 \%)$. Most of the respondents were not satisfied with the use of surface water as only $31.8 \%$ admitted satisfaction. The level of water obtained by the respondents varied from 1-50 litres to more than 500 litres everyday. Only $0.9 \%$ obtained over 500 litres while $29.0 \%$ fetch $1-50$ litres per day. Approximately, sixty four percent $(63.6 \%)$ claimed that the water bodies were scarce in their environment.
The period of water scarcity ranged from when much people were involved in fetching water $(4.0 \%)$ to the dry season period $(48.6 \%)$. Other uses attached to the water bodies include recreation, sports, religious worship, agriculture, fishing and tourism. Those who engaged in recreational (20.9\%) and agricultural $(20.1 \%)$ activities were the highest users while the lowest users were people on tourism (5.6\%).

Table 2: Respondents perception of surface water in

\begin{tabular}{llcc}
\multicolumn{4}{c}{ the study area } \\
\hline Variable & & Frequency & \% \\
\hline $\begin{array}{l}\text { Awareness } \\
\text { of surface }\end{array}$ & Yes & 260 & 81.0 \\
water bodies & Total & 61 & 19.0 \\
& & $\mathbf{3 2 1}$ & $\mathbf{1 0 0 . 0}$ \\
Types of & River & 121 & \\
surface & Stream & 102 & 37.7 \\
water bodies & Rivulets & 13 & 4.8 \\
& Ponds & 17 & 5.3 \\
& Lakes & 7 & 2.2 \\
& No response & 61 & 19.0 \\
& Total & $\mathbf{3 2 1}$ & $\mathbf{1 0 0 . 0}$ \\
\hline
\end{tabular}

Table 4 shows the perception of water quality and the method of treatment. The quality of the water obtained was unsatisfactory to the majority (50.2\%) of the respondents while $22.1 \%$ showed satisfaction. More than $70 \%$ of the respondents always purify the water before use. The various methods of water treatment ranged from herbs (2.8\%) such as Moringa oleifera in treating water to chemicals such as, Alum (46.7\%) for purification. However, $11.5 \%$ of the respondents adopted the traditional method of use of cloth to sieve their water before drinking. Table 5 also shows the types of diseases encountered by the respondents, other problems and solutions to the problems encountered. About $52.7 \%$ of the users of surface water bodies admitted they have contacted diseases such as diarrhea, cholera, malaria, bilharzias and dysentery due to surface water usage, with the variation of $6.2 \%$ (bilharzias) to $18.1 \%$ (malaria).

The problems encountered ranged from frequent clashes among most users $(5.6 \%)$ to long distance (29.3\%) covered by the respondents from the location of the water sources. The respondents suggested that, the solution to mitigating this problems include regular dredging, trimming of weed, boosting the tourist, prohibition of refuse dump into water and beautification.

The prohibition of refuse dump into water courses alone accounted for $43.3 \%$ of the respondents. Result revealed that males were more aware of the water bodies than females in the study area. More than half of the respondents were married with family size of 23 members. 
Table 3: The use of surface water in the study area

\begin{tabular}{|c|c|c|c|}
\hline Variables & & Frequency & $\%$ \\
\hline \multirow{8}{*}{$\begin{array}{l}\text { Reasons for } \\
\text { obtaining } \\
\text { water }\end{array}$} & Only source of water & 20 & 6.2 \\
\hline & $\begin{array}{l}\text { Do not obtain from } \\
\text { public source }\end{array}$ & 88 & 27.4 \\
\hline & $\begin{array}{l}\text { Prefer it to other } \\
\text { source }\end{array}$ & 24 & 7.5 \\
\hline & Easy access & 61 & 19.0 \\
\hline & Suitable for use & 25 & 7.8 \\
\hline & Natural state & 19 & 5.9 \\
\hline & No response & 84 & 26.2 \\
\hline & Total & 321 & 100.0 \\
\hline \multirow{5}{*}{$\begin{array}{l}\text { Rate of } \\
\text { obtaining } \\
\text { the water }\end{array}$} & Regularly & 63 & 19.6 \\
\hline & Occasionally & 67 & 20.9 \\
\hline & Rarely & 90 & 28.0 \\
\hline & No response & 101 & 31.5 \\
\hline & Total & 321 & 100.0 \\
\hline \multirow{4}{*}{$\begin{array}{l}\text { Satisfaction } \\
\text { Requirement }\end{array}$} & Yes & 102 & 31.8 \\
\hline & No & 129 & 40.2 \\
\hline & No response & 90 & 28.0 \\
\hline & Total & 321 & 100.0 \\
\hline \multirow{7}{*}{$\begin{array}{l}\text { Level of } \\
\text { water } \\
\text { obtained }\end{array}$} & 1-50 litres & 93 & 29.0 \\
\hline & 50-100 litres & 54 & 16.8 \\
\hline & 100-200 litres & 31 & 9.7 \\
\hline & 200-500 litres & 35 & 10.9 \\
\hline & Above 500 litres & 3 & .9 \\
\hline & No response & 105 & 32.7 \\
\hline & Total & 321 & 100.0 \\
\hline \multirow{4}{*}{$\begin{array}{l}\text { Scarcity of } \\
\text { water bodies }\end{array}$} & Yes & 204 & 63.6 \\
\hline & No & 44 & 13.7 \\
\hline & No response & 73 & 22.7 \\
\hline & Total & 321 & 100.0 \\
\hline \multirow{7}{*}{$\begin{array}{l}\text { Period at } \\
\text { which } \\
\text { scarcity is } \\
\text { common }\end{array}$} & During dry season & 156 & 48.6 \\
\hline & Heavy downpour & 25 & 7.8 \\
\hline & Much people & 13 & 4.0 \\
\hline & Flooding & 30 & 9.3 \\
\hline & Pollution & 28 & 8.7 \\
\hline & No response & 69 & 21.5 \\
\hline & Total & 321 & 100.0 \\
\hline \multirow{8}{*}{$\begin{array}{l}\text { Other uses } \\
\text { attached to } \\
\text { the water } \\
\text { bodies }\end{array}$} & Recreation & 67 & 20.9 \\
\hline & Sports & 32 & 10.0 \\
\hline & Religious Worship & 39 & 12.1 \\
\hline & Agriculture & 65 & 20.2 \\
\hline & Fishing & 46 & 14.3 \\
\hline & Tourism & 18 & 5.6 \\
\hline & No response & 54 & 16.8 \\
\hline & Total & 321 & 100.0 \\
\hline
\end{tabular}

The young people between the age of 15 and 25 years were the highest user of the water bodies in the study area. There activities were not limited to fetching of water but swimming and washing of cloths. This age range is more educated, adventurous, curious about the occurrences in their environment and interested in discoveries. Rivers and stream are the major sources of water supply and they accounted for $70 \%$ of all the water sources. Easy access and lack of public water supply were the major reasons for obtaining the water.

Water from borehole and hand-dug wells is believed to be safer than water from rivers, streams and lakes. It was also discovered that, large percentage of the respondents have regular access to the water bodies, while some does not. Some of the respondents have difficulties accessing the water bodies during dry season and whenever there is heavy down pour which often pollutes it. Other difficulties encountered include long distance before acquiring the water, too much patronage by other users and frequent clashes among users.

Table 4: Perception of water quality and treatment

\begin{tabular}{llcc}
\hline Variables & & Frequency & \% \\
\hline Satisfaction & Yes & 71 & 22.1 \\
with the & No & 161 & 50.2 \\
quality of the & No response & 89 & 27.7 \\
water & Total & $\mathbf{3 2 1}$ & $\mathbf{1 0 0 . 0}$ \\
The various & Use of cloth & 37 & 11.5 \\
methods used & Use of chemicals & 150 & 46.7 \\
for water & (Alum) & 9 & \\
treatment & Use of herbs & 36 & 2.8 \\
& Use of industrial & 89 & 27.7 \\
& No response & $\mathbf{3 2 1}$ & $\mathbf{1 0 0 . 0}$ \\
\hline
\end{tabular}

Table 5: Types of diseases encountered by the respondents, other

\begin{tabular}{|c|c|c|c|}
\hline Variables & Diseases & Frequency & $\% \mathrm{t}$ \\
\hline \multirow{7}{*}{$\begin{array}{ll}\text { Types } & \text { of } \\
\text { diseases }\end{array}$} & Diarrhea & 25 & 7.8 \\
\hline & Cholera & 35 & 10.9 \\
\hline & Malaria & 58 & 18.1 \\
\hline & Bilharzias & 20 & 6.2 \\
\hline & Dysentry & 31 & 9.7 \\
\hline & No response & 152 & 47.4 \\
\hline & Total & 321 & 100.0 \\
\hline \multirow{7}{*}{$\begin{array}{l}\text { Other } \\
\text { problems }\end{array}$} & Long distance & 94 & 29.3 \\
\hline & Too much demand & 47 & 14.6 \\
\hline & Impure state & 36 & 11.2 \\
\hline & Activities carried out & 82 & 25.5 \\
\hline & Frequent clashes & 18 & 5.6 \\
\hline & No response & 44 & 13.7 \\
\hline & Total & 321 & 100.0 \\
\hline \multirow{7}{*}{$\begin{array}{l}\text { Suggested } \\
\text { solutions to } \\
\text { problems } \\
\text { encountered }\end{array}$} & Regular dredging & 91 & 28.3 \\
\hline & Trimming of weed & 24 & 7.5 \\
\hline & Boosting the tourist & 20 & 6.2 \\
\hline & Prohibition of refuse & 139 & 43.3 \\
\hline & Beautification & 13 & 4.0 \\
\hline & No response & 34 & 10.6 \\
\hline & Total & 321 & 100.0 \\
\hline
\end{tabular}

The impure state of water quality for a long period of time, and the activities carried out by most users including religious worship and agriculture wastes such as herbicides and insecticides were found to be repulsive in the study area. Increasing disposal of wastes has caused a lot of environmental damage, and 
emphasizes the need to monitor, protect and manage water resources.

However, water quality should be preserved from the viewpoints of living environment for biota and the ecosystem. Impact of water pollution on these means direct and indirect adverse effects on human beings through the food chain and disturbances in the ecosystem (Umuhoza Mbateye et al., 2010). Defra (2001) found water pollution to be the environmental issue over which respondents had most concern, and concluded that $54 \%$ were concerned about pollution in rivers, bathing waters and beaches. As indicated in the result, most of the surface water users had contacted one disease or the other, including diarrhea, cholera, malaria, dysentry and bilharzias. Pimentel et al. (2004) reported that water pollution facilitates the spread of serious human diseases and diminishes water quality. They also observed that water shortage severely reduce biodiversity in both aquatic and terrestrial ecosystem, and threaten human food supply. Research commissioned by Scottish Government in 2006 demonstrated the importance of the water environment to people's quality of life, with about half stating that the water environment was very important to them (Dalrymple, 2006).

Conclusion: This study has shown many similarities between attitudes towards the water environment and other environmental issues, and a number of key findings that relate specifically to respondents relationship with water as a unique resource. It is evident that significant improvement in low water quality in the study area might lead to more recreational use of the environment, with consequent benefits for human well-being and the local economy when properly managed.

\section{REFERENCES}

Dalrymple, G; Hanley, N (2005). Using economic valuation to guide the management of outdoor recreation resources. Tourism. 53(2):105-114.
Davis, R; Hirji, R; Davis, R; Hirji, R (2003). Water quality: assessment and protection (English). Water Resources and Environment Technical Note ; no. D 1. Water Quality Management series. Washington, D.C.: The World Bank.

http://documents.worldbank.org/curated/en/51414146 8768597679/Water-quality-assessment-andprotection

DEFRA (2001). Survey of Public Attitudes to Quality of Life and to the Environment: DEFRA.

Ki-moon, B (2010). The human right to water and sanitation. Resolution A/RES/64/292. United Nations General Assembly, July 2010. http://www.un.org/waterforlifedecade/pdf/human _right_to_water_and_sanitation_media_brief.pdf

Marsalek, J; Jmenez Cisneros, B; Karamouz, M; Malmqvist, P.A; Goldenfum, J; Chocat, B (2006). Urban water cycle processes and interactions. Taylor and Francis, Leiden, The Netherland

Pimentel, D; Berger, BFD; Newton, MWB; Karabinakis, ECS; Poon, EAE; Nandaopal, S (2004).

Water Resource, Agriculture, and the Environment. Ithaca (NY): New York State College of Agriculture and Life Sciences, Cornell University. Report 04-1.

Turdukulov, UD (2003). Determination of Water Quality parameters using imaging spectrometry (Case study of Sajo floodplain, Hungary). The International Research Institute for Geoinformation science and Earth observation. Enschede, The Netherlands

Umuhoza Mbateye, FA; Nhapi, I; Wali, UG; Banadda, N (2010). Assessment of Wastewater Management practices in Kigali city, Rwanda. The Open Environ. Biologic. Monitor. J. 3: 2128. 